\title{
Drought reduces transmission of Turnip yellows virus, an insect-vectored circulative virus
}

\author{
Michel Yvon ${ }^{\mathrm{a}}$, Denis Vile ${ }^{\mathrm{b}}$, Véronique Brault ${ }^{\mathrm{c}}$, Stéphane Blanc ${ }^{\mathrm{a}}$, Manuella van Munster ${ }^{\mathrm{a}, *}$ \\ a INRA, UMR385, CIRAD TA-A54 K, Campus International de Baillarguet, 34398 Montpellier Cedex 05, France \\ b INRA, UMR759, 2 Place Viala, F-34060, Montpellier, France \\ ${ }^{\mathrm{c}}$ Université de Strasbourg, INRA, SVQV UMR-A 1131, 28 rue de Herrlisheim, 68021, Colmar, France
}

\section{A R T I C L E I N F O}

\section{Keywords:}

Vector transmission

Abiotic stress

Arabidopsis thaliana

Aphid

Turnip yellows virus

Polerovirus

\begin{abstract}
A B S T R A C T
Application of a severe water deficit to Arabidopsis thaliana plants infected with a mutant of Turnip yellows virus (TuYV, Family Luteoviridae) triggers a significant alteration of several plant phenology traits and strongly reduces the transmission efficiency of the virus by aphids. Although virus accumulation in water-stressed plants was similar to that in plants grown under well-watered conditions, virus accumulation was reduced in aphids fed on plants under water deficit. These results suggest alteration of the aphid feeding behavior on plants under water deficit.
\end{abstract}

\section{Introduction}

Plants suffer from a broad range of abiotic and biotic stresses that do not occur in isolation but are commonly present simultaneously (Mittler, 2006; Suzuki et al., 2014). On-going climate changes, mainly characterized by altered precipitation patterns, increased temperatures and levels of atmospheric $\mathrm{CO}_{2}$, are already affecting animal and plant populations (Parmesan and Hanley, 2015; Zhang et al., 2015), as well as agricultural productivity and human health (Sutherst, 2004; IPCC, 2014; Yusa et al., 2015). Phytoviruses also represent highly prevalent constraints in cultivated and wild species (Pagan et al., 2012; Roossinck, 2012) causing an estimated US $\$ 60$ billion losses in crop yield worldwide each year. Most of plant viruses rely on arthropods vector for transmission between host plants, and aphid vectors are by far outperforming all other members of the class Insecta ( $\mathrm{Ng}$ and Perry, 2004). However, virus transmission is mediated by critical successive processes starting from virus acquisition on an infected plant, then virus retention in the alimentary apparatus or in the aphid's body, and finally virus inoculation to a new plant (Bragard et al., 2013). Considering the major challenges posed by environmental changes to predict epidemiology of viral diseases, it is important to evaluate the effect of abiotic stresses on virus transmission rate by vectors, and particularly aphids. Global warming was shown to increase the abundance and geographic distribution of plant viruses and vectors (Gautam et al., 2013; Maino et al., 2016; Shaw and Osborne, 2011) and consequently a number of studies have been published on the influence of climate change on vector-borne diseases of plants and on their spread. Among these studies, those concerning viruses have mostly focused either on vector biology (e.g. developmental time, longevity, fecundity, migration) and ecology (Nancarrow et al., 2014; Scherm, 2004; Xie et al., 2014), or on virus accumulation and symptom expression in planta (Cronin et al., 2010; Fu et al., 2010; Trebicki et al., 2015). While most of these studies speculated on a possible impact of environmental changes on the rate of virus transmission, direct experimental support was only brought very recently (Chung et al., 2016; Dader et al., 2016; Nachappa et al., 2016).

Concerning the influence of a water deficit, we have recently shown that a severe water-deprivation treatment applied to Brassica rapa infected with Cauliflower mosaic virus (CaMV) or Turnip mosaic virus (TuMV), two non-circulative transmitted viruses, dramatically enhanced transmission rate by around $34 \%$ and $100 \%$, respectively (van Munster et al., 2017). Non-circulative transmission is the predominant strategy for plant virus-vector interaction in which the virus is taken up by a vector on an infected plant, attaches on the inner part of the cuticle lining the feeding apparatus (Uzest et al., 2007), and is subsequently released and inoculated into a new host plant. All three steps, acquisition, retention and inoculation, occur generally within seconds to minutes and do not require a passage within the vector's body. These viruses are mainly acquired during probing and transient puncturing of epidermal and mesophyll cells of infected leaf tissues (See for review Whitfield et al., 2015).

In case of circulative viruses, transmission is characterized by longer acquisition and inoculation periods (from hours to days), and long

\footnotetext{
* Corresponding author.

E-mail addresses: michel.yvon@inra.fr (M. Yvon), denis.vile@inra.fr (D. Vile), veronique.brault@inra.fr (V. Brault), stephane.blanc@inra.fr (S. Blanc), manuella.van-munster@inra.fr (M. van Munster).
} 
retention time in vector's body that can last several weeks, and often until the vector dies. These circulative viruses must cross several epithelia at the gut and salivary glands levels. This mode of transmission is found mainly for phloem-limited viruses belonging to the families Luteoviridae, Geminiviridae, and Nanoviridae (Blanc et al., 2014; Gray and Gildow, 2003; Sicard et al., 2015). Phloem-limited viruses are therefore acquired and inoculated by aphid vectors during long-lasting sap ingestions phases in sieve tubes (See for review Whitfield et al., 2015).

Due to these major differences between circulative vs. non-circulative transmission (e.g. acquisition and inoculation of the virus in different cell types, retention of the virus in the vector), information on impact of abiotic stresses on a large panel of plant-virus-vector system is desirable.

Turnip yellows virus (TuYV) is a circulative non-propagative aphid transmitted plant virus of the Luteoviridae family (genus Polerovirus). This virus is a major threat for oilseed rape (Brassica napus) where average yield losses can reach 30\% (Juergens et al., 2010) but is asymptomatic in Arabidopsis thaliana. Here, an engineered virus derived from TuYV and inducing leaf vein yellowing was used to evaluate the ability of the aphid Myzus persicae to transmit the virus from waterstressed A. thaliana plants compared to unstressed ones.

\section{Material and methods}

\subsection{Plant growth and drought stress protocol}

Seeds of Arabidopsis thaliana (L.) Columbia wild type (Col-0) were sown into individual $7 \times 7 \times 7 \mathrm{~cm}$ pots containing equal amount of organic substrate (Huminsubstrat N2, Neuhaus, pH 5.5-6.5; KlasmannDelmann GmBH, Geeste, Germany). Soil water content was controlled before sowing to estimate the amount of dry soil and water in each pot. Subsequent changes in pot weight were due mainly due to changes in water status. Dynamic changes in plant size could not be taken into account in calculations. These changes were negligible under WW but may have led to a maximum of $20 \%$ over-estimation under WD (data not shown). Plants were maintained in an insect-free walk-in growth chamber with $9 \mathrm{~h}$ light $(3600 \mathrm{~lx})$ set at $21 / 18^{\circ} \mathrm{C}$ (day/night) with $53 \%$ air relative humidity. Plants were irrigated with a nutritive solution (N $168 \mathrm{mg} \mathrm{L}^{-1}, \mathrm{P} 115 \mathrm{mg} \mathrm{L}^{-1}, \mathrm{~K} 336 \mathrm{mg} \mathrm{L}^{-1}, \mathrm{CaO} 162 \mathrm{mg} \mathrm{L}^{-1}, \mathrm{MgO}$ $19 \mathrm{mg} \mathrm{L}^{-1}$ ), maintaining the soil water content between 1.74 and $1.79 \mathrm{~g} \mathrm{H}_{2} \mathrm{O} \mathrm{g}^{-1}$ dry soil (depending on plant size) until virus agroinoculation.

A water-deprivation treatment (WD) was applied to half of the pots starting after virus inoculation (Day 0; see Section 2.2). Water-deprivation treatment was standardized as follows: no watering from Day 0 until reaching a soil water content between 0.14 and $0.18 \mathrm{~g} \mathrm{H}_{2} \mathrm{Og}^{-1}$ dry soil, depending on plant size. Soil water content of WD plants was then maintained to this value through an adequate supply of water until the transmission assays. We performed preliminary experiments to test that this level of soil water content was above permanent wilting point (growth recovered upon re-watering) for this plant species. The WD condition was reached after 17 days and maintained for 6 days until transmission experiments (Supplementary Fig. 1). In the well-watered treatment (WW) soil water content was maintained at $1.74-1.79 \mathrm{~g}$ $\mathrm{H}_{2} \mathrm{O} \mathrm{g}^{-1}$ dry soil.

Three consecutive experiments were carried out following the same experimental procedure.

\subsection{Virus inoculation of source plants by agroinoculation}

To produce virus-infected source plants, we used a modified TuYV virus, which induces vein clearing in A. thaliana (TuYV-SUL) while the wild-type virus is symptomless in this plant species (V. Ziegler-Graff, kind gift, unpublished results). This engineered virus allows direct visualization of the infection of plants. The modified sequence of the virus was placed under the control of the Cauliflower mosaic virus 35S promotor in a binary vector (pBinTuYV-SUL) and transformed into Agrobacterium tumefaciens strain GV3101 for agroinoculation (Leiser et al., 1992; V. Ziegler-Graff unpublished results). Briefly, Agrobacteria harboring pBinTuYV-SUL were grown for $48 \mathrm{~h}$ at $28^{\circ} \mathrm{C}$, pelleted and diluted in a buffer containing $10 \mathrm{mM}$ MES (pH 5.6), $10 \mathrm{mM} \mathrm{MgCl}_{2}$ and $0.15 \mathrm{mM}$ acetosyringone at an optical density (OD) at $600 \mathrm{~nm}$ of 0.5 . Agrobacteria suspension was incubated for $2 \mathrm{~h}$ at room temperature before being infiltrated to 5 week-old $A$. thaliana Col-0 plants.

\subsection{Aphid rearing}

The colony of aphid-vector species $M$. persicae was maintained on eggplants (Solanum melongena) in insect-proof cages, in a growth chamber at $23 / 18{ }^{\circ} \mathrm{C}$ (day/night) with a photoperiod of $14 / 10 \mathrm{~h}$ (day/ night), in conditions ensuring clonal reproduction. Aphids were transferred to new cages and to new host plants every two weeks, in order to avoid overcrowding and induction of the development of winged morphs.

\subsection{Measurements of plant source traits}

\subsubsection{Plant size}

Plant size was estimated 23 days after the start of WD treatment by measuring rosette diameter (mm) on TuYV- source plants (WW or WD).

\subsubsection{Fresh and dry weight, and water content measurements}

Aboveground tissues from each source plant used for transmission assays were collected and weighted to estimate the total fresh weight (FW) depending on the treatment (WW or WD). Aboveground tissues were then placed in an oven at $65{ }^{\circ} \mathrm{C}$ for $24 \mathrm{~h}$ for dry weight (DW) estimation. Water content (WC), i.e. the amount of water in leaves relative to its dry weight, was calculated as follows:

WC $(\mathrm{g} / \mathrm{g})=(\mathrm{FW}-\mathrm{DW}) / \mathrm{DW}$.

\subsection{Aphid transmission assays}

For transmission experiments, batches of twenty nymphs of $M$. persicae (L1-L2 stage) were starved for $1 \mathrm{~h}$ and then placed on a TuYVinfected source plant for $24 \mathrm{~h}$. Aphids were then collected and transferred individually to one month-old $A$. thaliana plantlets (test plants) grown and maintained under the WW condition for all the experiment. Aphids were confined on test plants by Falcon tube cages for an inoculation period of 3 days before insecticide treatment. Vein clearing symptoms were recorded three weeks later by visual inspection and the experiment was repeated three times.

Noteworthy, one biological replicate included the use of two aphids per test plant for the inoculation step. Estimated transmission rates by single aphid was then determined by the following formula: $Y=1-{ }^{n} \sqrt{ }$ (1-T), where $\mathrm{Y}=$ estimated transmission rate for one insect/plant, $\mathrm{n}=$ number insects per test plant $(\mathrm{n}=2), \mathrm{T}=$ experimental transmission rate (Nault et al., 1978).

\subsection{RNA extraction from $A$. thaliana source plants and $M$. persicae}

A. thaliana infected leaves were stored at $-80{ }^{\circ} \mathrm{C}$ before RNA extraction. Total plant RNA was extracted according to a modified Edwards protocol (Edwards et al., 1991) including an additional washing step with $70 \%$ ethanol, followed by a DNAse treatment (RQ1 RNase-free DNase, Promega).

Total RNA was extracted from whole $M$. persicae (15 aphids were pooled per sample) that had fed on TuYV-infected WW or WD plants for $24 \mathrm{~h}$. Aphids were then transferred to healthy plants for 2 days to clear the gut content from non-internalized virus particles. Aphids were 
Table 1

Primers used in the study.

\begin{tabular}{|c|c|c|c|c|}
\hline Gene/Target & Name & Primer sequence $\left(5^{\prime}-3^{\prime}\right)$ & Product size (bp) & Reference \\
\hline \multirow[t]{2}{*}{ TuYV (Capside) } & BpqtF0 & AAGACAATCTCGCGGGAAG & 139 & Reinbold et al. (2013) \\
\hline & BpqtR1 & GGAGACGAACTCCAAAATGAC & & \\
\hline \multirow{2}{*}{ A. thaliana UBC21 (At5g25760) } & UBC21-F & TGCAACCTCCTCAAGTTCGA & 72 & This study \\
\hline & UBC21-R & GCAGGACTCCAAGCATTCTT & & \\
\hline \multirow[t]{2}{*}{ M. persicae $R P L 7$} & RPL7_F & gCGCGCCGAGGCTTAT $^{\mathrm{a}}$ & 79 & Jaubert-Possamai et al. (2007) \\
\hline & RPL7_R & CCgGaTTTCTTTGCATTTCTTG ${ }^{\mathrm{a}}$ & & \\
\hline \multirow[t]{2}{*}{ M. persicae $L 27$} & L27_F & CCGAAAAGCTGTCATAATGAAGAC & 230 & Mutti et al. (2006) \\
\hline & L27_R & GGTGAAACCTTGTCTACTGTTACATCTTG & & \\
\hline
\end{tabular}

${ }^{a}$ In lower case: mismatches when hybridization on target sequence.

stored at $-80^{\circ} \mathrm{C}$ before RNA extraction. Aphids were first ground with a pestle in the RLT lysis buffer in Eppendorf tubes (Eppendorf, Hamburg, Germany) and RNA was extracted using the RNeasy Mini Kit (QIAGEN) following the procedure for animal tissue. Finally, RNA was eluted in $35 \mu$ l of RNase-free water prior to an additional DNAse treatment using RQ1 RNase-free DNase (Promega).

Quality and quantity of nucleic acid extraction was assessed by spectroscopic measurements at 230, 260 and $280 \mathrm{~nm}$ (NanoDrop 2000; Thermo Fisher Scientific), and by agarose gel electrophoresis. RNA extracts were stored at $-80{ }^{\circ} \mathrm{C}$ before used.

\subsection{Viral RNA quantification by $q R T-P C R$ in plants and in aphids}

One microgram of total RNA per sample was added to a mix containing $0.5 \mu \mathrm{g}$ of specific reverse primers (see Table 1 for details) and single-strand cDNA synthesis was done using Moloney Murine Leukemia Virus Reverse Transcriptase (M-MLV RT; Promega kit) according to manufacturer's instructions. DNA quantification was then performed in duplicates by real time quantitative PCR (qPCR) in 384-well optical plates using the LightCycler FastStart DNA Master Plus SYBRgreen I kit (Roche) in a LightCycler 480 thermocycler (Roche), following manufacturer's instructions. A specific set of primers designed for quantification of TuYV genome (BPqtF0 and BPqtR1, Reinbold et al., 2013) was used at a final concentration of $0.3 \mu \mathrm{M}$. All qPCR reactions were carried out with 40 cycles $\left(95^{\circ} \mathrm{C}\right.$ for $10 \mathrm{~s}, 60^{\circ} \mathrm{C}$ for $10 \mathrm{~s}$ and $72{ }^{\circ} \mathrm{C}$ for $\left.10 \mathrm{~s}\right)$ after an initial step at $95^{\circ} \mathrm{C}$ for $10 \mathrm{~min}$. A dissociation analysis $\left(60{ }^{\circ} \mathrm{C}-95^{\circ} \mathrm{C}\right)$ was performed after completion of the thermal PCR program to check the identity and purity of amplification products. The qPCR data were analyzed with LinReg PCR program to determine the efficiency of every single PCR reactions by linear regression of the exponential section of product curve (Ruijter et al., 2009).

The estimated initial concentration of TuYV in A. thaliana source plants, expressed in arbitrary fluorescence units $\left(\mathrm{N}_{0} \mathrm{TuYV}\right)$, was divided by that of $A$. thaliana ubiquitinating enzyme gene $\left(\mathrm{N}_{0} U B C 21\right.$; Genbank accession DQ027035), in order to normalize the amount of plant material analyzed in all samples. Noteworthy, UBC21 gene was shown to be stable in drought stress conditions (Wang et al., 2014) and was therefore used as reference gene. In the case of TuYV quantification within $M$. persicae, relative expression levels were normalized to mRNA initial concentration of RPL7 (Jaubert-Possamai et al., 2007) and L27 genes (Mutti et al., 2006).

\subsection{Statistical analysis}

All statistical analyses were performed in $\mathrm{R}$ environment for statistical computing (version 3.3.2). In experiment 3, effects of water deficit on plant size and on viral load in aphids were tested in an oneway ANOVAs. Effects of water deficit and experimental replicate on transmission rate were tested in a generalized linear model (GLM) ( $\mathrm{glm}$ function with binomial error distribution). Relationships between transmission rate and virus accumulation in source plants in both watering conditions were tested in linear regression after log- transformation of virus accumulation.

\section{Results and discussion}

A severe water deficit was applied to A. thaliana Col-0 plants infected with a mutant of TuYV (TuYV-SUL) modified to induce vein clearing (Fig. 1a), since TuYV wild-type does not induce visible symptoms on this plant species (V. Ziegler-Graff, personal communication). This modified virus was fully infectious in $A$. thaliana and its transmission by aphids was not affected when compared to the wild-type virus (V. Ziegler-Graff, personal communication). This engineered virus was used to inoculate plants and the symptom expressing plants were considered as positively infected in following experiments.

A negative effect of WD treatment on plant growth was observed. Three weeks after beginning of the WD, infected plant size showed a $30 \%$ significant reduction when compared to well-watered infected plants. Fig. 1b shows the results of one representative experiment out of the 3 performed $(p<0.001)$. At the end of the experiment (i.e. 23 days after the beginning of the WD protocol), leaf water content (WC) was about two times less important in plants grown under WD compared to well-watered plants $(p<0.001$; Fig. 1c). Given the drastic treatment applied to plants, the observed decrease of WC is consistent with that previously described in higher plants (Morgan, 1984).

In order to analyze the effect of water deficit on TuYV transmission by aphids, infected plants submitted to either WW or WD treatments were used as virus source in three independent transmission assays, as described in Material and methods. Aphids were allowed to acquire the virus on infected plants for $24 \mathrm{~h}$, and then deposited on test plants grown under standard conditions (WW). Test plants were visually screened 3 weeks later for the development of vein clearing symptoms. Overall, transmission of TuYV by M. persicae was reduced by $50 \%$ under WD compared to transmission from TuYV-infected plants under WW conditions ( $p<0.001$; Fig. 2). No significant variation in effect of WD on transmission rate was detected in the GLM between experimental replicates whether we used 2 aphids or 1 aphid per test plant for the inoculation step ( $p=0.36$; see Supplementary Fig. 2).

Whatever the treatment and the experimental repeat, no correlation could be found between virus accumulation in planta and aphid transmission efficiency (all $p>0.30$ ). Moreover, no difference in viral RNA accumulation was observed between plants submitted to WD or WW treatments $(p=0.89$; Fig. 3a). Interestingly, virus accumulation was significantly lower in aphids fed on plants under water deficit compared to aphids fed on WW plants (about 10 times less virus concentration in aphids fed on WD plants compared to WW plants) ( $p<0.001$; Fig. 3b), which may explain the $50 \%$ decrease of transmission efficiency using aphids fed on WD plants. Indeed, a positive correlation between viral load in the vector and virus transmission efficiency of circulative viruses has earlier been suggested (Gray et al., 1991).

Circulative viruses, including members of the family Luteoviridae, are acquired and delivered directly into phloem sieve elements by aphids during feeding (Douglas, 2006; Ziegler-Graff and Brault, 2008). 

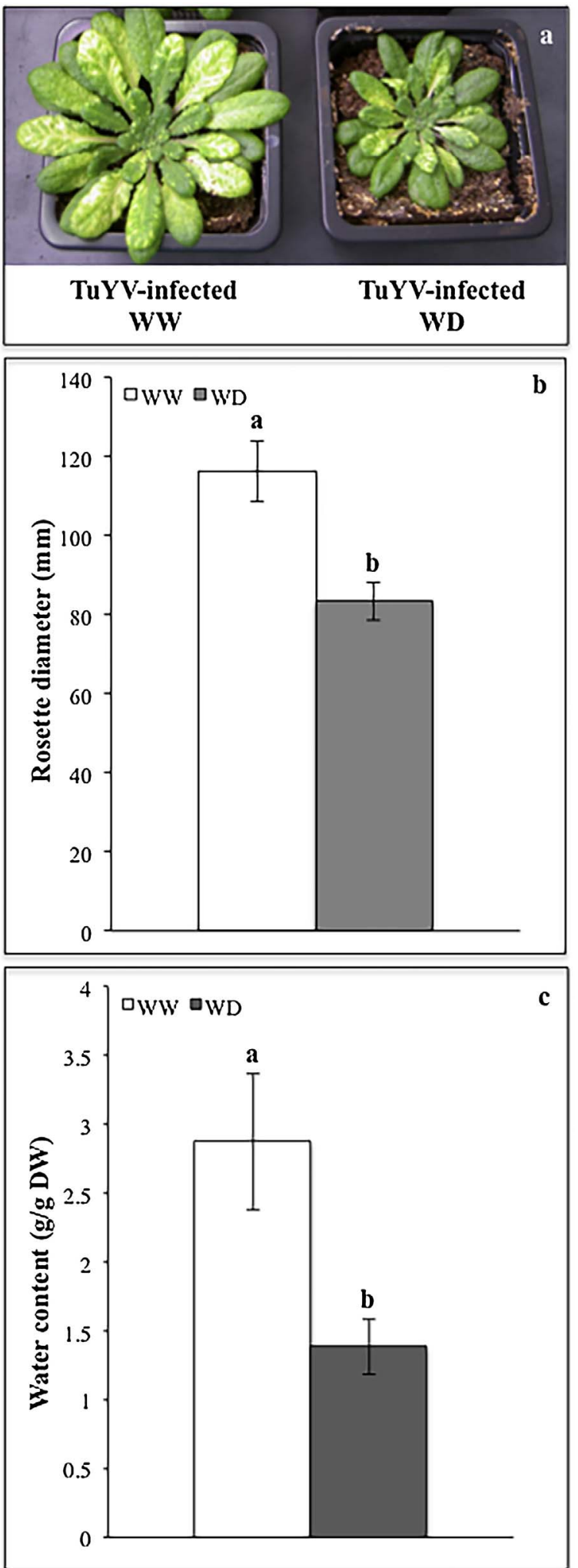

Fig. 1. Effects of water deficit treatment on TuYV-infected A. thaliana morpho-physiological traits. a) Vein clearing symptoms produced by TuYV-SUL on infected $A$. thaliana under well-watered (WW) or water deficit (WD) conditions 23 days after virus inoculation. b) Rosette diameter (in $\mathrm{mm}$ ) of virus source plants of one biological replicate ( $n=12$, for each treatment WW or WD), 23 days after the beginning of the WD treatment. c) Water content of TuYV-SUL infected source plants used in transmission assays $(n=3)$ was calculated from total fresh and dry weight of aboveground tissues as described in Material and methods. Bars represent standard error (SEM) and different lowercase letters indicate significant differences between water treatments according to a Student's $t$-test $(p \leq 0.05)$

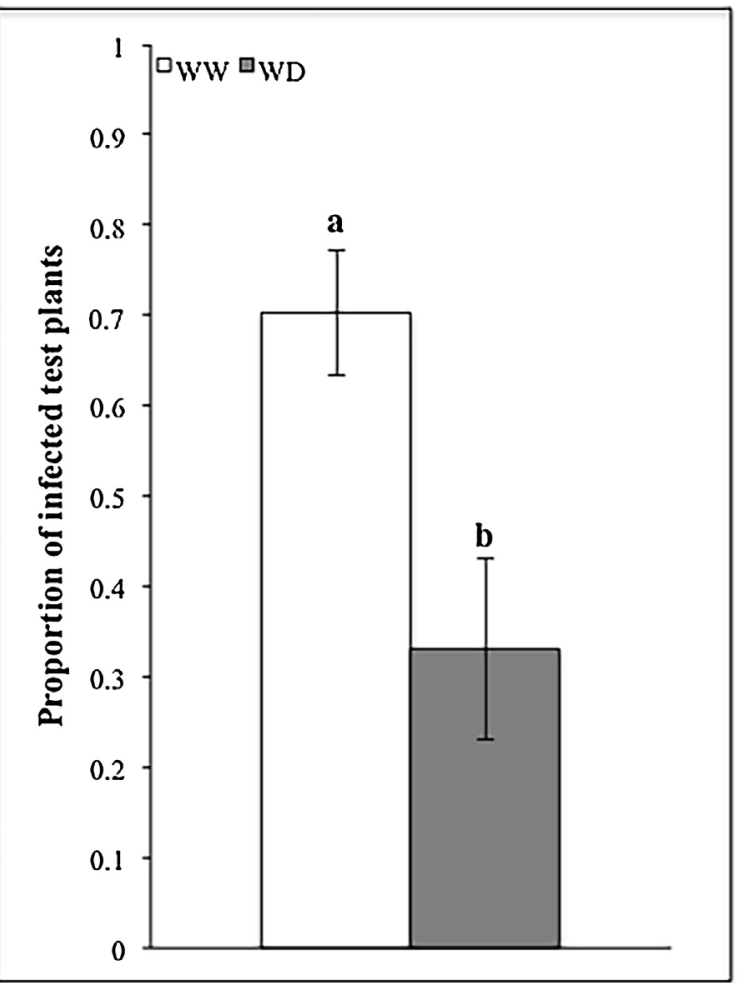

Fig. 2. Aphid-transmission of TuYV-SUL from A. thaliana plants grown under well-watered (WW) or water deficit (WD) conditions as virus source. Histograms indicate the average percentage of infected test plants from three independent experiments. Bars represent standard error (SEM) and different lowercase letters indicate significant differences between water treatments according to a $\chi^{2}$ test on the likelihood ratios $(p \leq 0.05)$.

Drought stress has been shown to significantly increase aphid feeding from xylem vessels (Vickers, 2011), because aphids must absorb xylem sap to balance the osmotic pressure of the sugar-rich phloem sap and avoid dehydration (Pompon et al., 2010, 2011). This behavioral change in the feeding process may reduce ingestion from the sieve tubes and thereby explain the observed reduction of virus uptake and internalization in aphid gut cells. Consistently, Guo et al. have recently reported that a water stress significantly decreased the phloem feeding phase of the aphid Acyrtosiphon pisum on Medicago truncatula (Guo et al., 2016), further supporting the finding that sustained aphid feeding on a host plant requires relatively high plant water potential to feed on phloem (Huberty and Denno, 2004).

At this point, however, other explanations cannot be excluded and will require further investigation. For example the virus concentration could drop specifically in the sieve elements upon water stress of the host plant (without significantly changing the overall accumulation in the plant) and decrease the efficiency of acquisition by aphids. Many other unknown factors may also be responsible for the observed decreased transmission under water deficit conditions. For example, we previously discussed the fact that the physiological status of the host plant could have a direct effect on the virus 'behavior' (Gutiérrez et al., 2013). We consistently showed that CaMV can "sense" the aphid feeding activity, as well as some abiotic stresses, and immediately and reversibly produce transmissible morphs (Martiniere et al., 2013). This remarkable phenomenon has been designated "transmission activation" (Drucker and Then, 2015), it can be triggered by abiotic stresses, and whether it also exist in virus species other than CaMV is unknown.

Additional alternative scenarios could easily be imagined but the unequivocal conclusion is that water stress, and abiotic stresses in general (e.g. temperature, $\mathrm{CO}_{2}$ ), can have dramatic effect on the transmission rate and thus on epidemiology of viral diseases (Chung et al., 2016; Dader et al., 2016; Nachappa et al., 2016; van Munster 

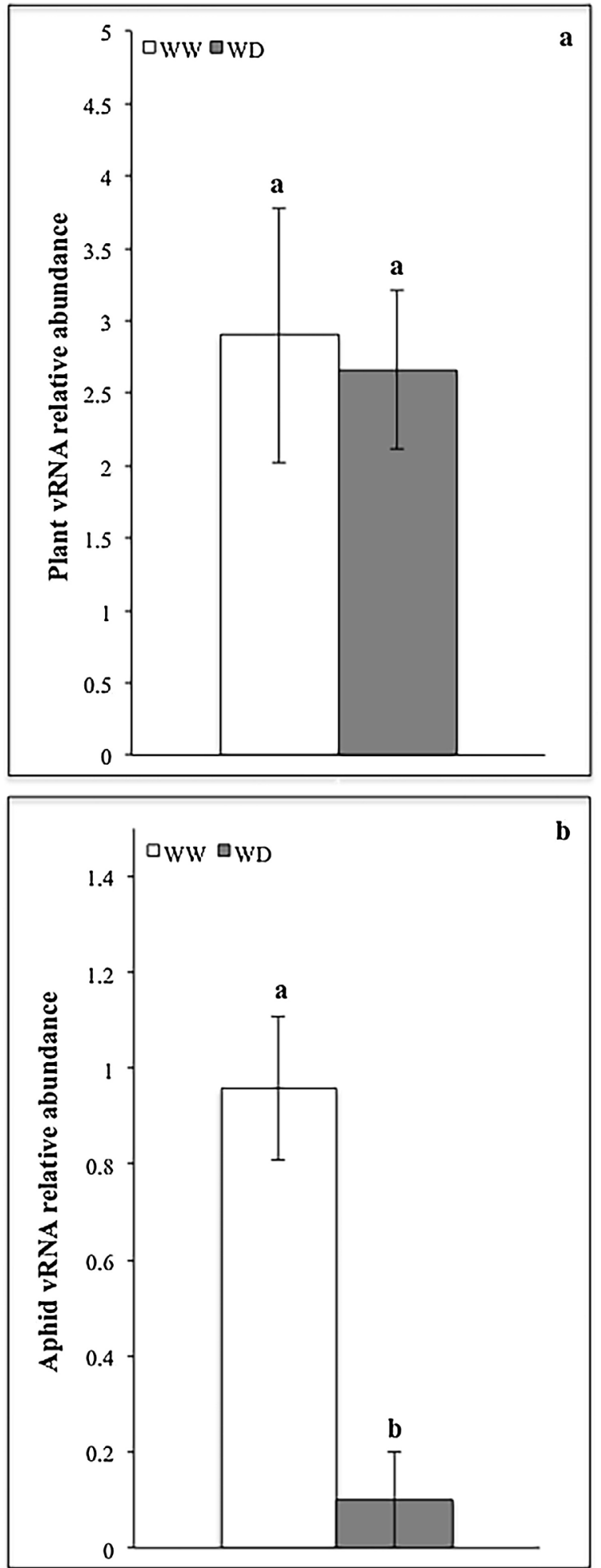

Fig. 3. TuYV-SUL accumulation in infected source plants and in the insect vector $M$. persicae. The relative viral RNA accumulation was measured by real-time RT-PCR in (a) TuYV-SUL infected plants in two biological replicates $(n=9$, for each WW or WD condition) and (b) $M$. persicae vector ( $\mathrm{n}=12$, for aphids fed on WW or WD TuYV-SUL infected plants). Normalization of the data was done using the $U B C 21$ reference gene in $A$. thaliana gene or the ribosomal house-keeping genes RPL7 and $L 27$ in M. persicae. Bars represent standard error (SEM) and different lowercase letters indicate significant differences between water treatments according to a Student's $t$-test $(p \leq 0.05)$. et al., 2017), and this point should be investigated in a large range of plant-virus-vector pathosystems.

\section{Acknowledgements}

We gratefully thank V. Ziegler-Graff for providing the construct pBinTuYV:SUL used in this study and for constructive discussions. We thank S. Leblaye and J.-L. Macia for technical assistance, plant care and aphid rearing.

This work was supported by a AAP-SPE-2014-2015 grant awarded to MvM by INRA.

\section{Appendix A. Supplementary data}

Supplementary data associated with this article can be found, in the online version, at http://dx.doi.org/10.1016/j.virusres.2017.07.009.

\section{References}

Blanc, S., Drucker, M., Uzest, M., 2014. Localizing viruses in their insect vectors. Annu. Rev. Phytopathol. 52, 403-426.

Bragard, C., Caciagli, P., Lemaire, O., Lopez-Moya, J.J., MacFarlane, S., Peters, D., Susi, P., Torrance, L., 2013. Status and prospects of plant virus control through interference with vector transmission. Annu. Rev. Phytopathol. 51, 177-201.

Chung, B.M., Canto, T., Tenllado, F., Choi, K.S., Joa, J.H., Ahn, J.J., Kim, C.H., Do, K.S. 2016. The effects of high temperature on infection by Potato virus $Y$, Potato virus A, and Potato leafroll virus. Plant Pathol. J. 32 (4), 321-328.

Cronin, J.P., Welsh, M.E., Dekkers, M.G., Abercrombie, S.T., Mitchell, C.E., 2010. Host physiological phenotype explains pathogen reservoir potential. Ecol. Lett. 13 (10), 1221-1232.

Dader, B., Fereres, A., Moreno, A., Trebicki, P., 2016. Elevated $\mathrm{CO}_{2}$ impacts bell pepper growth with consequences to Myzus persicae life history, feeding behaviour and virus transmission ability. Sci. Rep. 6, 19120-19130.

Douglas, A.E., 2006. Phloem-sap feeding by animals: problems and solutions. J. Exp. Bot. 57 (4), 747-754.

Drucker, M., Then, C., 2015. Transmission activation in non-circulative virus transmission: a general concept? Curr. Opin. Virol. 15, 63-68.

Edwards, K., Johnstone, C., Thompson, C., 1991. A simple and rapid method for the preparation of plant genomic DNA for PCR analysis. Nucleic Acids Res. 19 (6), 1349.

Fu, X., Ye, L., Kang, L., Ge, F., 2010. Elevated $\mathrm{CO}_{2}$ shifts the focus of tobacco plant defences from Cucumber mosaic virus to the green peach aphid. Plant Cell Environ. 33 (12), 2056-2064.

Gautam, H.R., Bhardwaj, M.L., Kumar, R., 2013. Climate change and its impact on plant diseases. Curr. Sci. 105 (12), 1685-1692.

Gray, S.M., Gildow, F.E., 2003. Luteovirus-aphid interactions. Annu. Rev. Phytopathol. 41, 539-566.

Gray, S.M., Power, A.G., Smith, A.G., Seaman, A.J., Altman, N.S., 1991. Aphid transmission of Barley yellow dwarf virus: acquisition access periods and virus concentration requirements. Phytopathology 81, 539-546.

Guo, H., Sun, Y., Peng, X., Wang, Q., Harris, M., Ge, F., 2016. Up-regulation of abscisic acid signaling pathway facilitates aphid xylem absorption and osmoregulation under drought stress. J. Exp. Bot. 67 (3), 681-693.

Gutiérrez, S., Michalakis, Y., van Munster, M., Blanc, S., 2013. Plant feeding by insect vectors can affect life cycle, population genetics and evolution of plant viruses. Funct. Ecol. 27, 610-622.

Huberty, A.F., Denno, R.F., 2004. Plant water stress and its consequences for herbivorous insects: a new synthesis. Ecology 85 (5), 1383-1399.

IPCC, 2014. Climate Change 2014: Impacts, Adaptation, and Vulnerability. Part A: Global and Sectoral Aspects. Contribution of Working Group II to the Fifth Assessment Report of the Intergovernmental Panel on Climate Change. Cambridge University Press, Cambridge, United Kingdom and New York, NY, USA.

Jaubert-Possamai, S., Le Trionnaire, G., Bonhomme, J., Christophides, G.K., Rispe, C., Tagu, D., 2007. Gene knockdown by RNAi in the pea aphid Acyrthosiphon pisum. BMC Biotechnol. 7, 63-70.

Juergens, M., Paetsch, C., Kramer, I., Zahn, M., Rabenstein, F., Schondelmaier, J., Schliephake, E., Snowdon, R., Friedt, W., Ordon, F., 2010. Genetic analyses of the host-pathogen system Turnip yellows virus (TuYV)-rapeseed (Brassica napus L.) and development of molecular markers for TuYV-resistance. Theor. Appl. Genet. 120 (4), 735-744.

Leiser, R., Ziegler-Graff, V., Reutenauer, A., Herrbach, E., Lemaire, O., Guilley, H., Richards, D., Jonard, G., 1992. Agroinfection as an alternative to insects for infecting plants with Beet Western Yellows Luteovirus. Proc. Natl. Acad. Sci. U. S. A. 89, 9136-9140.

Maino, J.L., Kong, J.D., Hoffmann, A.A., Barton, M.G., Kearney, M.R., 2016. Mechanistic models for predicting insect responses to climate change. Curr. Opin. Insect Sci. 17, 81-86.

Martiniere, A., Bak, A., Macia, J.L., Lautredou, N., Gargani, D., Doumayrou, J., Garzo, E., Moreno, A., Fereres, A., Blanc, S., Drucker, M., 2013. A virus responds instantly to the presence of the vector on the host and forms transmission morphs. Elife 2, e00183.

Mittler, R., 2006. Abiotic stress, the field environment and stress combination. Trends 
Plant Sci. 11 (1), 15-19.

Morgan, J.M., 1984. Osmoregulation and water stress in higher plants. Annu. Rev. Plant Physiol. 35, 299-320.

Mutti, N.S., Park, Y., Reese, J.C., Reeck, G.R., 2006. RNAi knockdown of a salivary transcript leading to lethality in the pea aphid, Acyrthosiphon pisum. J. Insect Sci. 6, 1-7.

Nachappa, P., Culkin, C.T., Saya, P.M., Han, J., Nalam, V.J., 2016. Water stress modulates soybean aphid performance, feeding behavior, and virus transmission in soybean. Front. Plant Sci. 7, 552-567.

Nancarrow, N., Constable, F.E., Finlay, K.J., Freeman, A.J., Rodoni, B.C., Trebicki, P., Vassiliadis, S., Yen, A.L., Luck, J.E., 2014. The effect of elevated temperature on Barley yellow dwarf virus-PAV in wheat. Virus Res. 186, 97-103.

Nault, L.R., Styer, W.E., Coffey, M.E., Gordon, D.T., Negi, L.S., Niblett, C.L., 1978. Transmission of Maïze chlorotic mottle virus by chrysomelid beetles. Phytopathology 68, 1071-1074.

Ng, J.C., Perry, K.L., 2004. Transmission of plant viruses by aphid vectors. Mol. Plant Pathol. 5 (5), 505-511.

Pagan, I., Gonzalez-Jara, P., Moreno-Letelier, A., Rodelo-Urrego, M., Fraile, A., Pinero, D., Garcia-Arenal, F., 2012. Effect of biodiversity changes in disease risk: exploring disease emergence in a plant-virus system. PLoS Pathog. 8 (7). http://dx.doi.org/10. 1371/journal.ppat.1002796.

Parmesan, C., Hanley, M.E., 2015. Plants and climate change: complexities and surprises. Ann. Bot. 116 (6), 849-864.

Pompon, J., Quiring, D., Giordanengo, P., Pelletier, Y., 2010. Role of xylem consumption on osmoregulation in Macrosiphum euphorbiae (Thomas). J. Insect Physiol. 56 (6), 610-615.

Pompon, J., Quiring, D., Goyer, C., Giordanengo, P., Pelletier, Y., 2011. A phloem-sap feeder mixes phloem and xylem sap to regulate osmotic potential. J. Insect Physiol. 57 (9), 1317-1322.

Reinbold, C., Lacombe, S., Ziegler-Graff, V., Scheidecker, D., Wiss, L., Beuve, M., Caranta, C., Brault, V., 2013. Closely related poleroviruses depend on distinct translation initiation factors to infect Arabidopsis thaliana. Mol. Plant Microbe Interact. 26 (2), 257-265.

Roossinck, M.J., 2012. Plant virus metagenomics: biodiversity and ecology. Annu. Rev. Genet. 46, 359-369.

Ruijter, J.M., Ramakers, C., Hoogaars, W.M.H., Karlen, Y., Bakker, O., van den Hoff, M.J.B., Moorman, A.F.M., 2009. Amplification efficiency: linking baseline and bias in the analysis of quantitative PCR data. Nucleic Acids Res. 37 (6), 45-56.

Scherm, H., 2004. Climate change: can we predict the impacts on plant pathology and pest management? Can. J. Plant Pathol. 26, 267-273.

Shaw, M.W., Osborne, T.M., 2011. Geographic distribution of plant pathogens in response to climate change. Plant Pathol. 60 (1), 31-44.

Sicard, A., Zeddam, J.L., Yvon, M., Michalakis, Y., Gutierrez, S., Blanc, S., 2015. Circulative nonpropagative aphid transmission of nanoviruses: an oversimplified view. J. Virol. 89 (19), 9719-9726.

Sutherst, R.W., 2004. Global change and human vulnerability to vector-borne diseases. Clin. Microbiol. Rev. 17 (1), 136-173.

Suzuki, N., Rivero, R.M., Shulaev, V., Blumwald, E., Mittler, R., 2014. Abiotic and biotic stress combinations. New Phytol. 203, 32-43.

Trebicki, P., Nancarrow, N., Cole, E., Bosque-Perez, N.A., Constable, F.E., Freeman, A.J., Rodoni, B., Yen, A.L., Luck, J.E., Fitzgerald, G.J., 2015. Virus disease in wheat predicted to increase with a changing climate. Global Change Biol. 21 (9), 3511-3519.

Uzest, M., Gargani, D., Drucker, M., Hebrard, E., Garzo, E., Candresse, T, Fereres, A. Blanc, S., 2007. A protein key to plant virus transmission at the tip of the insect vector stylet. Proc. Natl. Acad. Sci. U. S. A. 104 (46), 17959-17964.

van Munster, M., Yvon, M., Vile, D., Dader, B., Fereres, A., Blanc, S., 2017. Water deficit enhances the transmission of plant viruses by insect vectors. PLoS One 12 (5), e0174398.

Vickers, L., 2011. Aphid Responses to Drought: a Combined Physiological and Transcriptomic Approach. PhD Thesis. Birmingham University (260 pp.).

Wang, Z., Chen, Y., Fang, H., Shi, H., Chen, K., Zhang, Z., Tan, X., 2014. Selection of reference genes for quantitative reverse-transcription polymerase chain reaction normalization in Brassica napus under various stress conditions. Mol. Genet. Genomics 289, 1023-1035.

Whitfield, A.E., Falk, B.W., Rotenberg, D., 2015. Insect vector-mediated transmission of plant viruses. Virology 480, 278-289.

Xie, H., Zhao, L., Wang, W., Wang, Z., Ni, X., Cai, W., He, K., 2014. Changes in life history parameters of Rhopalosiphum maidis (Homoptera: Aphididae) under four different elevated temperature and $\mathrm{CO}_{2}$ combinations. J. Econ. Entomol. 107 (4), 1411-1418.

Yusa, A., Berry, P., Cheng, J.J., Ogden, N., Bonsal, B., Stewart, R., Waldick, R., 2015. Climate change, drought and human health in Canada. Int. J. Environ. Res. Public Health 12, 8359-8412.

Zhang, W., Rudolf, V.H.W., Ma, C.-S., 2015. Stage specific heat effects: timing and duration of heat waves alter demographic rates of a global insect pest. Oecologia 179 (4), 947-957.

Ziegler-Graff, V., Brault, V., 2008. Role of vector-transmission proteins. Methods Mol Biol. 451, 81-96. 